\title{
H.E. Wiegand Receives an Honorary Doctorate from the University of Stellenbosch
}

On 20 April 2006, the degree Doctor of Literature, Honoris Causa, was conferred on H.E. Wiegand by the University of Stellenbosch. The decision by the Council and the Senate to award him this degree has been taken on the grounds of the following considerations stated in the commendatio read at the graduation ceremony.

Herbert Ernst Wiegand, professor emeritus at the University of Heidelberg in Germany, has made an immense contribution over the years to theoretical lexicography, Germanic studies and linguistics.

In lexicographic research, he has played a leading role in the establishment of a comprehensive and complex theory that offers lexicographers from all language groups a model for the compilation of dictionaries.

As a scientist, Wiegand has made a contribution of unparalleled scope. His impressive list of publications bears testimony to this contribution, particularly his magnum opus, the book Wörterbuchforschung, and the most comprehensive contribution to the broader field of linguistics, the authoritative reference series, Handbücher zur Sprach- und Kommunikationswissenschaft, which was established by him.

As research manager he initiated the journal Lexicographica and the book series Lexicographica Series Maior, which contains more than a hundred books for the subject specialist. He compiled the book series Studien zur neuhochdeutschen Lexikographie, Wörterbücher in der Diskussion and Studien zur zweisprachigen Lexikographie mit Deutsch, and is a founding member of the book series Reihe Germanistische Linguistik, a series in which more than 260 books have already been published.

In Afrikaans, South African and broader African lexicography, Wiegand's theoretical methods of approach have also resulted in research and dictionary projects. His involvement with Afrikaans lexicography has led him to include Afrikaans as one of the languages in the decalingual Dictionary of Lexicography and Dictionary Research.

The Pan South African Language Board established National Lexicography Units for each of the eleven South African official languages. Their training programmes are largely based on Wiegand's model from which adaptations and applications have been made so that each dictionary unit could find guidelines for the compilation of a dictionary directed at the specific needs and reference skills of its target user group. 
Wiegand's influence in Africa is also evident from the research of doctoral students from Gabon in the postgraduate programme for lexicography at the University of Stellenbosch. All these students work within the framework of the Wiegand model.

As professor, study supervisor, promoter and academic manager Wiegand has enriched his field of study. He has been promoter of no less than 44 doctor's degree students.

His work has been acknowledged in a variety of ways, for example through a commemorative conference, a Festschrift, the publication of his Kleine Schriften, and honorary doctorates from the Aarhus School of Business in Denmark and the University of Sofia in Bulgaria.

At the celebration after the graduation ceremony, Professor Elize Botha, Chancellor of the University of Stellenbosch, while welcoming the guests, referred to the honorary doctorates, especially expressing her appreciation for the attention given to lexicography.

In the absence of Professor Walter Claassen, Vice-Principal: Research, Professor Rufus Gouws proposed a toast to Professor Wiegand to which he responded as follows:

Your appreciative words really mean a lot to me. I am grateful and would like to thank you ever so much. Baie baie dankie! I can assure you that I am proud of this new honorary doctorate of mine. There are three reasons for feeling proud about it.

The first reason is the fact that the University of Stellenbosch is not only regarded as one of the three most distinguished universities within Africa but also has an excellent reputation and standing internationally.

The second reason is based on the definite knowledge that the honorary doctorate from the University of Stellenbosch has been awarded to me as an acknowledgement of my scientific work and not, for example, for being a sponsor or a donor of whatever nature.

The third reason I regard as by far the most important. With this honour bestowed on me today the status of the research area in which I have primarily, although not exclusively, worked during the last two decades, has been enhanced in a way that should not be underestimated.

This gives me the opportunity to make a few brief comments on the role of the University of Stellenbosch in the field of lexicography and metalexicography.

The University of Stellenbosch, represented by Professor Walter Claassen, the Vice-Principal: Research, has acknowledged that lexicography should be promoted in the interest of everyone living in South Africa. Furthermore he has recognized, and this should be noted, that this cannot prevail by merely promoting lexicographic processes as a practice, because this practice needs to be supported by a modern theoretical underpinning. In this regard he is of the same opinion as our colleague, Professor Bernard Lategan, the Director of the Stellenbosch Institute for Advanced Study, whom I would like to thank on this 
occasion for the privilege of being a fellow of his institute where I may pursue my research. Both Professor Claassen and Professor Lategan are furthermore in agreement with my esteemed colleague, Rufus Gouws, who has always striven towards this theoretical underpinning, without forgetting that the practice has its own dynamics.

For the past two and more decades the University of Stellenbosch has actively supported the continued endeavours of Professor Gouws to establish contacts on national and international level with the leading exponents in the field of dictionary research. The results are quite evident: The University of Stellenbosch, along with the Bureau of the WAT and its outstandingly edited journal Lexikos, in which internationally established as well as emerging African researchers publish, has become an internationally renowned centre for dictionary research. In 1986 at a conference of the European Association for Lexicography, it had been demanded on political grounds that the South African Gouws should leave the conference. This, however, was avoided. Nowadays people travel to Stellenbosch for their research, and Professor Gouws is not only invited to the big international conferences but also to the small elite conferences of Europe. He participates in the most important major international projects in the field of metalexicography, for example the Dictionary of Lexicography and Dictionary Research and the Supplementary Volume to the Encyclopedia of Lexicography in the series Handbücher zur Sprach- und Kommunikationswissenschaft, to mention only two projects. This international network, promoted by Professor Claassen, and to the realisation of which I have also directed my efforts, benefits not only the University of Stellenbosch and the Stellenbosch students specifically, but also South African lexicography in general.

That this may also prevail in future, I would like to toast with everyone present today. 